\title{
POLITICAL BOUNDARIES AND TERRITORIAL IDENTITY IN EARLY MODERN CENTRAL EUROPE: THE WESTERN FRONTIER OF TRANSYLVANIA DURING THE SIXTEENTH CENTURY
}

\author{
Florin Nicolae ARDELEAN \\ Babeş-Bolyai University, Academic Cultural Heritage Department, The Archive of Babeș-Bolyai University, \\ Cluj-Napoca, ROMANIA \\ florinardelean1@yahoo.com, (Dhttps://orcid.org/0000-0001-9071-889x \\ DOI: http://doi.org/10.23740/TID120212
}

\section{ABSTRACT}

The last decades have witnessed an increased interest in the research of territorial delimitations in late medieval and early modern Europe. A significant part of the academic debate has been focused on identifying and defining the process of transition from medieval frontiers, perceived as vague areas of contact, to modern linear borders. The aim of this article is to analyse the organisation of the western confines of the Transylvanian Principality during the decades in which this state was formed, from the Ottoman conquest of Buda (1541) until the ratification of the Speyer Peace Treaty (1571). Throughout this period, the territorial delimitation of Transylvania from the Ottoman Empire and Habsburg Hungary was an ongoing process, marked by both military confrontations and diplomatic negotiations. Through a critical reassessment of the most relevant Romanian and Hungarian literature on this complex subject and the analysis of new data from official and narrative contemporary sources, I have tried to identify which were the most important political and military events that shaped the western borderlands of Transylvania. A fundamental objective of my research is to provide an accurate definition for the western region of the Transylvanian Principality, contributing thus to the general debate on the nature of frontiers/borders in sixteenth century Europe.

\section{INTRODUCTION}

Political and cultural boundaries represent important research subjects for scholars in the fields of humanities and social sciences. Regardless of their academic background, most authors preoccupied with this complex issue have tried to define, as accurate as possible, the basic concepts of boundary, border, and frontier. The three notions are often used interchangeably and sometimes cause confusion or misunderstanding. This is a particularly pressing issue when dealing with the subject of political boundaries from a historical perspective. In this article, I have used the term boundary as a general notion that implies territorial, political, military, and cultural delimitations. At the same time, boundary encompasses the more specific terms of frontier and border. Borders are usually defined as 
static and restrictive. Frontiers are characterised as transition zones, porous and fluid (Langer \& Fernández-Götz, 2020).

The term frontier has been generally used to describe territorial delimitations in medieval Europe. Nevertheless, it remains a complex and ambiguous notion. It is not so much an identifiable phenomenon as it is a conceptual tool used by historians. A frontier should not be regarded only as a place, but also as a set of attitudes, social conditions, and relationships (Abulafia, 2016). Borders are primarily political and administrative. They emphasise the limits of political control and indicate the extent of a certain territorial identity (Power, 1999). Borders, as clear-cut lines of demarcation, were bom at the end of the seventeenth and beginning of the eighteenth century, in connection with the development of modern cartography (Power, 1996; Baramova, 2010; Esser \& Ellis, 2013). The linearisation of borders began in the early modern period, but it continued as a global process even after the Two World Wars (Goettlich, 2019).

Previous historical research on the subject of medieval and early modern boundaries has emphasised the relation between core and periphery, between hinterland and borderland. Each zone had its specific social and economic dynamics (Power, 1999; Abulafia, 2016). This approach is very relevant for our particular case study because the regions that divided the emerging Transylvanian Principality from its powerful neighbours, the Ottomans and the Habsburgs, maintained several political, military and social particularities. The building of this political boundary is closely linked to the formation of the early modern Transylvanian state. It was a frontier which delimitated a territorial identity with older origins, which survived even after the region was occupied by the Habsburgs at the end of the seventeenth century.

\section{TRANSYLVANIA BETWEEN THE OTTOMANS AND THE HABSBURGS (1526-1551)}

In the Middle Ages, the voivodeship of Transylvania was a province of the Hungarian Kingdom. A region situated in the eastern parts of the Carpathian Basin, Transylvania maintained a distinct status within the lands of the Crown of Saint Stephen. The voivode of Transylvania was one of the highest-ranking officials in the Hungarian Kingdom. Usually members of the high nobility (barones), those who held this important office exercised administrative, juridical, and military authority in their province (Jakó, 1989-1993; Kovács, 2005).

From the end of the Fourteenth century, Hungary was engaged in a prolonged conflict with the Ottoman Empire. The military competition between the two powers was dominated by an almost constant state of frontier warfare, which exhausted the resources of Hungarian kings (Pálosfalvi, 2018, p. 9). The Ottomans struck a decisive blow in the battle of Mohács (29 August 1526) and, during the following decades, the Realm of Saint Stephen was divided into three parts: the southern and central regions were occupied by the Turks culminating with the conquest of Buda in 1541, the western and northem regions acknowledged the authority of the Habsburgs, and the eastern parts, including Transylvania, pledged their loyalty to King John Szapolyai. However, the situation was far from being stable, and the three factions continued to fight for the territorial heritage of the Hungarian Crown. In this complicated political context, Transylvania and some additional territories from the eastem parts of the former Hungarian kingdom (the so called Partium regni Hungariae), were gradually organised into a distinct state, the Principality of Transylvania (Feneșan, 1997; Oborni, 2004; Ardelean, 2019, pp. 11-13). 
In 1528, John Szapolyai reached an agreement with the Ottomans and received the protection of the sultan. After one decade of conflict, Szapolyai began negotiations with Ferdinand of Habsburg. A peace treaty was signed at Oradea (Várad/Waradinum) in 1538 and later ratified by both monarchs. King John agreed that after his death all his territories would recognise the authority of the Habsburg Hungarian King. However, one year later, he married Isabella Jagiello, daughter of the Polish King. Queen Isabella gave birth to a son and thus, in spite of all odds, House Szapolyai had an heir to the throne. On his deathbed, King John obtained an oath of fealty from all his followers who swore to defend the infant John Sigismund and protect his claim to the Hungarian throne (Fodor \& Oborni, 2020, pp. 127-136). The attempt of reunification established through the peace treaty of Oradea was nullified and Transylvania was one step closer to becoming a distinct state.

The separation of Transylvania from the rest of the kingdom was a rather long process, which is best illustrated by the establishment of a new frontier in the region situated between the Western Carpathians and the Tisza River. The Ottoman conquest of Buda in 1541 and the Peace Treaty of Speyer, ratified in 1571, mark the beginning and the end of this process (Ardelean, 2008-2009; Fodor \& Oborni, 2020, p. 129).

When he occupied the royal seat of the Hungarian kings, Süleyman the Magnificent decided to entrust Transylvania to the son of King John, the infant John Sigismund Szapolyai. The initial plan was to directly occupy this part of the kingdom as well, but the sultan decided to focus his attention on the greater danger, the Habsburgs. Nevertheless, Süleyman considered himself the rightful ruler of whole Hungary and, from his perspective, Transylvania and the other territories were already Ottoman provinces (sanjak), and their rulers (John Sigismund, Peter Petrovic and friar George Utješenović were considered Ottoman district governors (bey) (Feneșan, 1999-2000; Fodor \& Oborni, 2020, p. 129, pp. 139-140). However, the Ottomans never managed to completely integrate these territories in the administrative framework of their Empire. The transformation of Transylvania into a tributary state, like Moldavia and Wallachia, proved to be the best solution at that moment. A favourable context for the development of a new state was thus created.

The process would have been incomplete without the formation of a new political and territorial identity among the social elites of the region. This new identity can be traced in the documents issued during the separate assemblies of the estates (Diets) from Transylvania and the Partium region. In this particular case, territorial identity was linked to personal loyalty to the Szapolyai family. In a report on the Diet gathered in Târgu Mureș (Marosvásárhely), in January 1542, the author clearly states that Transylvania and the territories beyond the Tisza River were under the rule of the son of King John (Regio et Pars Regni Hungariae, ultra Thyciam et Regnum Transy/vanicum collata sunt filio Regis Joannis) (Szilágyi, 1876a, p. 77). Sultan Süleyman also acknowledged the River Tisza as a dividing line between the two territories. Gradually, the estates of Partium and Transylvania had to acknowledge the division of the kingdom and gathered separately. In the Diet of Turda (Torda/Thorenburg), held in August 1544, the Transtibiscan counties (counties situated east of the Tisza River) legally joined the Transylvanian Diet. The attendants declared themselves "lords and nobles from Transylvania and the Hungarian territories under the jurisdiction of Her Majesty" (Per universitatem Dominorum et Nobilium Regni Transsiluanie et Hungarie ditionis Maiestatis suae) (Szilágyi, 1876a, p. 188). This common identity was also expressed in diplomatic documents. For example, in 1548, Queen Isabella sent a delegation to Ferdinand of Habsburg. The letter of credence was signed by the queen herself, George Martinuzzi and the Transylvanian and Transtibiscan nobles (Legatio 
Serenissimae Reginae Isabellae fratris Georgij ac Nobilium Transsyluaniensium atque eorum qui trans Tibiscum sunt) (Szilágyi, 1876a, pp. 243-244).

\section{TRANSYLVANIA UNDER HABSBURG RULE (1551-1556)}

In 1551 Ferdinand of Habsburg managed to extend his authority over Transylvania. The influential George Martinuzzi (Utješenović/Utješenić) joined his side and Queen Isabella decided to relinquish the throne. Very unsatisfied with this political change, the Sultan was unable to take immediate action because his military forces were concentrated in Asia at the time. For almost six years Transylvania was governed by representatives of the Habsburg King of Hungary. During the first phase (1551-1553), this position was held by General Giovanni Battista Castaldo as military governor (rebus bellicis locumtenens, capitaneus generalis). He led an army of foreign mercenaries (mostly German and Spanish) and soldiers from Upper Hungary to enforce the Habsburg rule in Transylvania and protect its frontiers from Ottoman aggressions (Ardelean, 2017; Korpás \& Szabó, 2020). The foreign army generated social tension in Transylvania and was unable to efficiently defend its frontiers from Ottoman incursions. In this context, Ferdinand I decided to relocate his Spanish and German troops and instead appointed two voivodes in May 1553. One was Ferenc Kendi, a representative of the Transylvanian nobility, and the other was István Dobó, a nobleman from Upper Hungary and acclaimed military commander (Jakó, 1989-1993, pp. 43-44; Feneșan, 1997, pp. 153-155).

Although a large part of the territories of the Hungarian Crown were at that time under the control of the Habsburgs, an effective union was far from being achieved. The Diet of Transylvania and the Partium region continued to assemble separately from the rest of Hungary. The estates acknowledged the Habsburg rule but negotiated a series of legal provisions meant to maintain their status and the security of the country (pro conservatione nostrae patriae) (Szilágyi, 1876a, pp. 342-344). In the following years the representatives of the estates continued to meet with regularity, usually twice a year. They identified themselves as "lords of all estates and orders of Transylvania" (dominorum omnium statuum et ordinum regni Transiluaniae) (Szilágyi, 1876a, p. 404). Military aspects, including the defence of frontiers, were often debated during Diet sessions (Ardelean, 2019, pp. 59-60).

Castaldo was an experienced military commander and understood the defensive potential of Transylvania. His army was accompanied by several Italian architects (Alessandro da Urbino, Sigismondo da Pratovecchio, etc.) who worked on the modernisation and consolidation of older fortresses and fortified towns. They had a fundamental contribution to the spread of bastioned (Italian type) fortifications in this region (Kovács, 2012, pp. 165-167; Masi, 2015, p. 45). Among the fortifications modernised during this period (1551-1553) were: Sibiu (Hermannstadt/Nagyszeben), the citadel of Brașov (Kronstadt/Brassó), Alba lulia (Gyulafehérvár/Weißenburg), Sebeș (Mühlbach/ Szászsebes), Gherla (Szamosújvár/ Neuschloss), Lipova (Lippa) and Timișoara (Temesvár/Temeschwar).

The strongest Ottoman offensive targeted Timișoara and the surrounding area. A first attempt of conquest failed in 1551. One year later, in 1552, a larger Ottoman force laid siege to Timișoara. Without any hope of relief, the defenders, led by István Losonczy, decided to surrender (Czimer, 1893; Molnár, 2020). It was an important territorial loss and the Transylvanian estates blamed it on the Habsburgs. Timișoara, Șoimuș and Lipova were considered important frontier fortifications that were lost too easily by the commanders of 
Ferdinand: Constat autem majestati sue annis superioribus quantis calamitatibus et periculis hec misera nostra patria affecta et quantis fortunae procellis jactata vndique fuerit, Temeswarinum, Solymos, Lyppa alieque quam plurime arces in confinibus vno momento omnes periere... (Szilágyi, 1876a, p. 493).

In 1556 Ferdinand lost Transylvania. Isabella Jagiellon and her son, John Sigismund, the elected king of Hungary, returned as rightful rulers with consistent political and military help from their liege lord, the Ottoman Sultan. In order to consolidate their rule, the Sultan agreed to recognise a clearer separation between Transylvania and the neighbouring Ottoman provinces. This initiative, although not very successful, was very important in recognising the new political entity that was Transylvania (Fodor \& Oborni, 2020, p. 144).

\section{BUILDING A MILITARY BORDERLAND ON THE WESTERN EDGES OF TRANSYLVANIA (1551-1571)}

In 1556, the inhabitants of Transylvania and especially those from the borderland counties in the Tisza region were once again faced with two political options: loyalty towards the heir of King John Szapolyai or allegiance to the Habsburg King of Hungary (Horn, 2012, pp. 26-150). It was not a simple choice and many nobles from the frontier area wavered between the two options. The Tisza River was no longer a clear delimitation between the lands of the two monarchs. Territorial changes occurred frequently during the following years and the shape of the frontier was determined by the personal loyalty of the "marcher lords" - influential nobles from the borderland who took an active part in the war between the two factions.

From their return to Transylvania in October 1556 and until the ratification of the Speyer Peace Treaty in 1571, Queen Isabella and her son John Sigismund Szapolyai were at war with the Habsburgs. Direct confrontations were often interrupted by diplomatic negotiations and armistices. Although the reason for this war was the right of inheritance over the Hungarian Crown, each faction was interested in expanding its political control over the disputed borderland area. A direct consequence of this prolonged military confrontation was the birth of the western frontier of the Principality of Transylvania.

\section{THE BANAT OF CARANSEBEȘ AND LUGOJ}

In his descriptions of Transylvania, written in 1564 and 1567, Giovanandrea Gromo shows a particular interest in fortifications. Gromo was an Italian mercenary captain in the guard of John Sigismund Szapolyai, who also performed diplomatic missions for his employer. His accounts are considered valuable narrative sources, mostly based on his personal experience and direct observations (Veress, 1929, pp. 250-258; Gromo, 1945; Holban et al., 1970, pp. 312372). The boundaries of the realm ruled by John Sigismund Szapolyai are an important subject in both texts. Their presentation begins with the southern sector of the western frontier, represented by the Banat of Caransebeș and Lugoj. The most important fortifications of this administrative unit were the towns of Caransebeș and Lugoj and the fortresses of Mehadia and Jdioara.

Caransebeș was defended by a stone wall and a dry moat, which were improved by the Italian architects bought by general Castaldo in 1551-1553 (Holban et al., 1970, p. 317, p. 329; Groza, 
1993). Lugoj was an open market town with a smaller but well defended citadel. This town had an important strategic position because of its proximity to Timișoara and Gyula. Timișoara was the administrative centre of a new Ottoman province after 1552 and Gyula was an important fortification controlled by the Habsburgs (Veress, 1929, p. 251; Holban et al., 1970, p. 345).

The highest military and administrative authority in this area was held by the ban. His residence was in the town of Caransebes where he commanded a retinue of 500 cavalry (Holban et al., 1970, p. 329). The bans of Caransebeș and Lugoj (banus districtuum Caransebeş et Lugos) also held the official title of count of Severin, because the two administrative denominations overlapped from the beginning of the sixteenth century (Magina, 2013a). One of the major office holders in the country, the ban was chosen from the close supporters of the ruler (Țigău, 1998).

One of the most influential personalities who held this office was Peter Petrović of Suraklin (Zraklin). Descendent of a noble family from Požega County in Slavonia, he was a close relative of John Szapolyai (probably cousin). Petrović began his political career as a member of the retinue of John Szapolyai and remained loyal to him and his heirs for the rest of his life. During the reign of King John, Petrović received his most important offices in the Banat area: captain of Lipova fortress (1530), count (comes) of Timiş and captain general of the Lower Parts of Hungary (1533). His most important estates were also concentrated in this area (Magina, 2015, pp. 139-147). In 1540, on his deathbed, King John appointed him as one of the guardians of the infant John Sigismund. In the following years Petrović fulfilled his oath and became one of the most trusted advisors of Queen Isabella.

In 1551, when Transylvania was lost to the Habsburgs, Petrović exchanged his proprieties in the Timiș area for the fortress of Munkács and its estates. Later, he joined Isabella and John Sigismund at the court of the Polish King, Sigismund II August, where they prepared for regaining Transylvania. Petrović had great influence among the Serbian population of the Banat and was in excellent relations with the Ottomans. In 1554 he was able to return there, and the Ottoman sultan granted him the towns of Caransebeș and Lugoj, which had been conquered during the 1552 campaign (Varga, 2020). The Banat of Caransebeș and Lugoj became thus the power base of the Szapolyai loyalists. Petrović initiated the offensive in the beginning of 1556 and during the following months he was able to chase the remaining supporters of the Habsburgs out of Transylvania. Due to his political heritage, the Banat of Caransebes and Lugoj remained loyal to the elected rulers of Transylvania and was a stable bulwark on the south-western frontier of the country until 1658 when it was conquered by the Ottomans.

\section{THE DEFENCE ALONG THE MUREȘ VALLEY}

The valley of the Mureș River was one of the main ways of access to Transylvania. During the middle of the sixteenth century, the region traversed by this river, from the Western Carpathians to the Tisza River, was a zone of intense confrontations between the Habsburgs and the Ottomans. During the 1551 and 1552 Ottoman campaigns, a large part of this region, including territories situated north of the river Mureș were occupied by the Turks, for shorter or longer periods.

The fortifications of Lipova and Șoimoș represented the most important strategic defensive points from a Transylvanian perspective and were important proprieties of the Szapolyai 
family. King John had raised Lipova to the status of a free royal borough in 1528. In 1541, when Buda was captured by the Ottomans, Queen Isabella moved to Lipova where she and her son resided until 1542, when they moved to Alba Iulia (Dörner, 2018, pp. 500-506). While Șoimoș was a medieval stone fortress situated on a tall outcrop on the banks of the Mureș River, Lipova was a large, fortified settlement situated in its vicinity. According to contemporary observers, Lipova had three defensive elements: a large oval rampart of wood and earth (palancă), a smaller stone enceinte and an inner citadel. In 1551, the Italian architect Sigismundo da Pratovecchio, was sent to oversee the preparation of Lipova for the expected Ottoman attack (Magina, 2013b, p. 276).

On the $8^{\text {th }}$ of October 1551, Lipova was occupied by the Turkish army which was attempting to isolate Timișoara. The siege of Timișoara failed because of the bad weather and the determination of its defenders, but many other smaller fortifications in the Banat were under Ottoman control. In this context, Martinuzzi and Castaldo decided to launch a swift counteroffensive in spite of the harsh winter. Their main objective was Lipova, defended at the time by a large Ottoman garrison of 4,000 soldiers. During the second half of November, a large army gathered under the walls of Lipova: the troops gathered by the Transylvanian estates, nobles from Upper Hungary, bishop Martinuzzi with his large personal retinue, Castaldo with his Spanish and German mercenaries and Sforza Pallavicini with 3,500 mercenaries (mostly Germans) (Centorio, 1565, p. 108; Szakály, 1986, pp. 172-181). Despite the great disproportion in numbers, the besiegers were unable to take Lipova by force. Martinuzzi suggested negotiations and entrusted one of his faithful servants, the Croatian noble Gaspar Perušić, to contact the Ottoman officers. In the end, the Turks decided to surrender the fortress if they were allowed to leave unharmed. An agreement was reached but a few days later the Ottomans were attacked on their way to Belgrade by a band of local nobles and Spanish mercenaries (Ardelean \& Isailović, 2021, p. 229).

The defence of Lipova was entrusted to the Spanish commander (maestre de campo) Bernardo de Aldana. An experienced soldier who had served for many years in the armies of Charles $\mathrm{V}$, Aldana realised that his task would be a very difficult one. In 1552, the Ottomans organised a new, better prepared, offensive in Banat. This time they managed to conquer Timișoara and it was only a matter of time before all the other smaller fortifications in the area fell. In this context, the Spanish commander decided to abandon Lipova. He was accused of treason, sentenced to death, and absolved before the execution. Aldana continued to serve the Habsburg Monarchy for several years and eventually died in the naval battle of Djerba (Tunisia), in 1560 (Korpás, 2000, pp. 882-884).

During the following decades, Lipova was an Ottoman border fortification defended by a permanent garrison. The number of soldiers residing inside the defensive perimeter varied between 120 and 222 (Hegyi, 2007, pp. 1447-1450). In 1595, during the Long Turkish War (15911606), the army of Prince Sigismund Báthory managed to retake Lipova after a four-day siege and the fortress was reintegrated in the defensive system of Transylvania (Cîmpeanu, 2018).

While Lipova was in the hands of the Turks (1552-1595), Deva became the most important Transylvanian frontier fortification along the Mureș Valley. According to Giovannandrea Gromo, Deva defended the most dangerous entrance into Transylvania. The fortress had an excellent position on a high cliff overlooking the river (Holban et al., 1970, p. 341). It was an older medieval fortress which was partially modernised during the second half of the sixteenth century. In 1565, a tax of 75 denars per household was collected in Hunedoara County for the consolidation of Deva fortress (Prodan, 1967, p. 416). 
In 1553, Deva was defended by a small permanent garrison of 20 cavalry and 20 infantry (Ardelean, 2019, p. 155). In case of emergency, the captain of the fortress was able to mobilise a larger defensive force from the surrounding settlements. He was considered and important military official of the country and sometimes joined the main army of the Transylvanian ruler. During the 1564 campaign for example, the captain of Deva reached the camp of John Sigismund Szapolyai with a retinue of 300 horsemen (Holban et al., 1970, pp. 366-368). Like all other fiscal fortresses (fortifications under the direct authority of the elected ruler of Transylvania), Deva was surrounded by an estate which provided for the necessity of the garrison and the administrative staff. Towards the end of the sixteenth century, this estate consisted of 40 settlements (38villages and 2 market towns) (Veress, 1933a, p. 142).

Throughout this period, Deva remained a stable possession of the Transylvanian rulers. The fortress had an excellent defensive potential and was not seriously threatened by enemy armies, but the surrounding territory was affected by small scale military actions, typical for frontier areas. Various forms of early modern irregular warfare (raids, ambushes, and skirmishes) were very common in the borderlands and were not always conditioned by official relations between neighbouring states. Peace treaties and armistices were not enough to stop small scale hostilities usually determined by economic or political reasons. Such confrontations usually involved smaller groups, recruited locally.

In September 1550, for example, loan Kendefi gathered a band of nobles from Hațeg (Hátszeg) district and attacked the troops sent by the Ottomans and the voivode of Wallachia. The confrontation took place near Turnu Roșu (Rothenturm/Vöröstorony), in the defile of Olt River, and the Transylvanian nobles were victorious. A similar confrontation took place on $16^{\text {th }}$ of November, this time in Hațeg district. Sensing the political change in Transylvania, Kenedfi and his supporters were trying to gain the favour of George Martinuzzi by showing their willingness to fight for the Habsburg cause (Feneșan, 2016, pp. 310-311). The County of Hunedoara provides another interesting example of local mobilisation for the defence of the frontier during the same year, 1550. Count (ispán) János Török gathered a small army of 113 horsemen and 673 pedestrians and attacked the Ottoman troops led by Kasim Pasha in the vicinity of Deva. The young count of Hunedoara had more than one reason to join the Habsburgs and held a personal grudge against the Turks who had imprisoned his father, Bálint Török. The battle was remarkable because of a duel between the leader of the small Transylvanian army and an Ottoman officer, Feru ağa. Török was victorious and his deed of bravery was immortalised in a poem by Sebestyén Tinódi (Ardelean, 2019, p. 47).

\section{ZARAND COUNTY}

Further north, Zarand County encompassed a frontier area where the delimitation between Transylvanian, Habsburg and Ottoman authority changed frequently. The most important fortifications in this area were: Șiria (Világosvár), Ineu (Borosjenő), and Dezna (Dézna). A large part of the region was occupied by the Ottomans during the 1552 campaign. In the following years, the Habsburgs were able to retake the lost territories, including the above-mentioned fortresses. Another major territorial change occurred in 1565, after another large-scale Ottoman expedition which targeted the fortress of Szigetvár. On this occasion, the main fortifications of Zarand County were conquered by the Ottomans. While Ineu and Șiria were reinforced with Turkish garrisons, Dezna was given to John Sigismund Szapolyai. One year later (1566), the Habsburg general Lazarus Freiherr von Schwendi managed to retake the 
fortifications, but Ottoman authority was reinstated in the area, after the sultans' campaign against Szigetvár (Lukinich, 1918, pp. 139-153; Hegyi, 2019, p. 314). A few decades later, during the Long Turkish War (1591-1606), both Șiria and Ineu were conquered by the troops of György Borbély and were reintegrated in the western defensive system of Transylvania (Ardelean, 2019, p. 122).

In 1552, Șiria was supplied by a small estate consisting of 13 settlements. Beyond its strategic and military importance, Șiria and the surrounding territories were valuable because of the silver and gold exploitations, especially those from Baia de Criș (Körösbánya) (Holban et al., 1970). Ineu was considered a stronger fortification and was improved with modem bastions during the second half of the sixteenth century. The fortress was well supplied with weapons and gunpowder but its estate, consisting of ten settlements, was impoverished by the frequent military confrontations. By the beginning of the seventeenth century, the villages around Ineu were home to only 90 families with very little possessions (Magina, 2011).

\section{ORADEA, THE CENTERPIECE OF THE TRANSYLVANIAN WESTERN FRONTIER}

During the Middle Ages, Oradea was the centre of an important bishopric in the eastern half of the Hungarian Kingdom. At the middle of the sixteenth century, this important ecclesiastical office was held by George Martinuzzi. The cathedral and the palace of the bishop were protected by a stone fortification. In 1556, the Habsburg garrison of the fortress was among the few who resisted the Transylvanian troops of Peter Petrović. One year later, they negotiated a peaceful surrender and Oradea passed under the authority of Queen Isabella. The construction of the modern fortification began in 1569 and it had a pentagonal plan (with five bastions). It was finished later, in the first decades of the seventeenth century and it was the strongest bastioned fortification of the Transylvanian Principality (Anghel, 1972, p. 117; Marta, 2013, pp. 35-50).

The construction of Oradea fortress was probably the most ambitious and costly project of Transylvanian rulers in the Early Modern Age. Money, materials and labour force were acquired through general contributions (special taxes paid by the whole country) and the income generated by the estate of the fortress. By the middle of the sixteenth century, the Bishopric and Chapter House of Oradea cumulated a very large estate in Bihor (Bihar) County, of 4,761 fiscal units (households). In 1556, the proprieties of the Catholic Church in Transylvania were secularised and became part of the fiscal estate. The former ecclesiastic domains in Bihor County were assigned to the fortress of Oradea (Jakó, 1940, p. 190; Maksay, 1990, pp. 239-253).

After 1557, Oradea became the most important fortification on the western frontier of Transylvania. It remained under the authority of Queen Isabella and John Sigismund Szapolyai throughout the conflict with the Habsburgs, which ended in 1571 with the ratification of the Speyer Peace Treaty. The captain of Oradea fortress was one of the highest positions in the military hierarchy of the country. Stephen Báthory of Somlyó held this office from the beginning of the 1560s until 1571, when he was elected ruler (voivode) of Transylvania. In this early phase of his exceptional career, Stephen (István) Báthory was one of the most influential Transylvanian "marcher lords". He held an important office in the frontier area (captain of Oradea fortress), most of his family estates were situated in the western borderlands and he played an active role in the military confrontations with the Habsburgs. On the $4^{\text {th }}$ of March 
1562, in the battle of Hodod, he brought 500 soldiers from the garrison of Oradea and commanded the right flank of the Transylvanian army. The Transylvanians suffered a crushing defeat and Stephen Báthory was wounded during the battle (Miles, 1670, pp. 83-85; Hegyi, 1900, pp. 142-244; Veress, 1933b, pp. 32-33). In 1564 Báthory was appointed captain general (supreme commander) of the Transylvanian army and led a successful campaign in Satu Mare County. Through cunning and military strength, he was able to temporarily expand the northwestern frontier of Transylvania (Ardelean, 2017, p. 346).

\section{THE NORTH-WESTERN FRONTIER - ȘIMLEU, CHIOAR AND HUST}

The north-western frontier of Transylvania encompassed a very large region that included the counties of Crasna (Kraszna), Middle Szolnok (Közép Szolnok), Inner Szolnok (Belső Szolnok) and Maramureș (Máramaros).

Situated in the Crasna County, Șimleu (Szilágysomlyó /Șimleul Silvaniei) was the most important estate of the Transylvanian branch (Somlyai) of the Báthory family. During the second half of the sixteenth century, a bastioned fortification was built around an older medieval castle. Two market towns and 47 villages provided for the needs of the fortress and its garrison. An inventory made during the last decade of the sixteenth century mentions various weapons and significant quantities of ammunition: one heavy gun, seven bombards, 97 harquebuses, 6 rifles, 6,600 harquebus shots, 619 bombard shots, 34 barrels of gunpowder, lances, spears, arrows, etc. The fortress was defended by 10 mercenary guardsmen, 113 free guardsmen and 19 free horsemen (Wolf, 1981, pp. 400-403; Kovács, 2013, pp. 95-106).

The fortress of Chioar was built in the aftermath of the Mongol invasion of 1241. Like many other Transylvanian fortifications, it was modernised during the second half of the sixteenth century. Its large estate included one market town and 66 villages. The defence of the fortress was entrusted to a small resident garrison aided by semi-privileged groups (freemen, riflemen) who lived in the nearby settlements (Prodan, 1967, p. 593; Hossu, 2003, pp. 17-19).

The northern edge of the Transylvanian frontier was guarded by the fortress of Hust (today Chust/Хуст in Ukraine). Built on a high ridge along the Tisza River, Hust dominated a borderland section that divided Transylvania, Habsburg Hungary, and Poland. In 1546, the fortress was occupied by troops loyal to Ferdinand I of Habsburg. Later, in 1556, Peter Petrović was able to retake this fortification for the Szapolyai faction. In 1567 the army of Lazarus Schwendi laid siege to Hust but failed to take fortress. The older stone fortification was modernised during this period. The first bastion was built in 1550, while Hust was under Habsburg control (Deschmann, 1991, pp. 156-164). The estate of Hust was smaller than the other Transylvanian fortress estates. It had only 205.5 fiscal units (households) spread in 16 settlements (Maksay, 1990, pp. 479-486).

In this region, the most reliable supporter of the Szapolyai family was Kristóf Hagymássy. He held the office of captain of Hust fortress for a very long time. During the war with the Habsburgs, he was appointed captain general two times, in 1557 and in 1566. Each time he shared this office with another influential noble. In 1568, John Sigismund Szapolyai rewarded him with the fortress and estate of Chioar. Although frontier fortifications were usually part of the fiscal estate, and thus under the direct authority of the ruling prince, in this particular case John Sigismund decided to decentralise the burden of frontier defence. By this time Hagymássy had proven his loyalty to the Szapolyai family and his capacity to defend the section of frontier that was 
entrusted to him. In 1571, Hagymássy was one of the three nobles (together with Mihály Csáky and Gáspár Bekes) who supervised the fulfilment of John Sigismund's testament. His decision to support Setphen Báthory as ruler of Transylvania was fundamental in maintaining the western defensive system of the country (Ardelean, 2019, pp. 116-117).

\section{TEMPORARY EXPANSION IN NORTH-EAST HUNGARY - MUNKÁCS, SATU-MARE AND TOKAJ}

During the so called "Fortress War of the North-East" (1556-1565), Ferdinand I of Habsburg, and later his heir Maximilian II, fought against John Sigismund Szapolyai for the control of a large borderland region which roughly encompassed the counties of: Satu Mare (Szatmár), Ugocsa, Bereg, Szabolcs, Ung, Zemplén, and Abaúj. For almost a decade, this vast region turned into a buffer zone where the limits of political authority were unclear and strongly linked to the personal loyalty of the local nobility (Virovecz, 2021, pp. 101-116). The major fortifications of the region like Szatmár (today Satu-Mare in Romania), Munkács (today Mukacevo in Ukraine) and Tokaj represented essential strategic points for each faction. The possession of one of these large fortifications ensured an efficient control over local resources and tax collection.

In 1551, when the Habsburgs expanded their control over Transylvania, Peter Petrović agreed to exchange his possessions in the Banat area for the castle and estate of Munkács in Bereg County. When the rule of the Szapolyai family in Transylvania was restored in 1556, Munkács became their main outpost in Upper (North-East) Hungary. After the death of Petrović, the command of the fortress was entrusted to another loyal supporter of Queen Isabella, Tamás Daczó. Although he was a member of the lesser nobility, Daczó earned the trust of the queen in September 1558 when he attacked and killed Ferenc Bebek, an influential noble from Hungary who was plotting to assassinate Isabella and her son. According to contemporary sources, Tamás Daczó together with Gaspar Perušić killed Ferenc Bebek after a long and exhausting fight (Ardelean \& Isailović, 2021, p. 231). Although most nobles from this area acknowledged Habsburg authority, Daczó remained loyal to the Szapolyai family (Virovecz, 2021, pp. 109-110). The Habsburgs were able to retake the fortress only in 1567, after a successful campaign led by Lazarus Schwendi.

The settlements of Sătmar (Szatmár) and Mintiu (Németi) (today Satu Mare/Szatmárnémeti) occupied an important strategic and economic position along the lower course of the Someș River. The construction of a bastioned fortification began in 1565, while the region was under Habsburg control (Kovács, 2009, p. 28). One of the largest and strongest fortifications in the area, Satu Mare, was situated on a vast estate consisting of 186 settlements (villages and market towns), inhabited by 6,540 serfs and theirfamilies (Diaconescu, 2012, p. X).

After 1556, Satu Mare and the surrounding areas were firmly under Transylvanian control. Although it was initially an estate of the Báthory family, in 1559, Queen Isabella donated it to Menyhárt Balassa. Balassa was at the time the strongest "marcher lord" in Upper Hungary and his loyalty to the Szapolyai family was a guarantee for maintaining Transylvanian authority in the region. In December 1561, Balassa decided to change factions and consequently, John Sigismund Szapolyai lost control over most of his north-western frontier, including Satu Mare (Virovecz, 2017, 2021, p. 102; Ardelean, 2021, pp. 19-21). Stephen Báthory led a successful campaign in June 1564 and managed to retake Satu Mare for the Transylvanian faction.

At the beginning of the following year, the Habsburgs prepared a strong counter-offensive commanded by Lazarus Schwendi. With an army of 7,000 soldiers, Schwendi, Balassa and Miklós Báthory (of Ecsed) were able to retake several important fortifications from the borderlands 
including Tokaj, Satu Mare and Chioar (Feneșan, 2001, p. 35). After these events Satu Mare remained firmly under Habsburg control for the following decades. Following the suggestions of Lazarus Schwendi, Habsburg authorities decided to organise a new section of frontier beyond the Tisza River with the commander of Satu Mare as captain general. The holder of this office had authority over the garrisons of Satu Mare, Kálló, Kisvárda, and Ecsed (Pálffy, 2000, pp. 46-47).

Tokaj was another major fortification disputed by the Szapolyais and the Habsburgs. Beyond its strategic importance, the value of Tokaj consisted in its vineyards. The excellent wine produced in the area was a precious commodity coveted by both warring factions. Major conflicts but also the occasional frontier raids stopped during the harvest. Such a situation occurred in 1557 when the leader of the Transylvanian army and Imre Thelekessy, captain general of Kassa (today Košice in Slovakia) signed an armistice because of the bad weather that was threatening to ruin the grape harvest (Szilágyi, 1876b, p. 27).

The Szapolyai family was able to extend their authority over Tokaj when its captain, Ferenc Némethi, decided to pledge his loyalty to Queen Isabella in 1556. Until his death in 1564, Némethi remained loyal to the rulers of Transylvania and enforced their control over Tokaj and the surrounding area. In 1558, Némethi initiated the construction of a modern (bastioned) fortification. He gathered a considerable garrison of 100 cavalry, 100 infantry and a few light artillery pieces to defend it. Like all other "marcher lords", Némethi organised frequent raids on the estates of nobles who had sworn loyalty to the Habsburgs. On such occasions, he was able to mobilise up to 1,000 soldiers (700 cavalry and 300 infantry). When help arrived from Transylvania, he attempted to take larger fortifications like Kisvárda in 1558 (Németh, 2005, pp. 74-88). János, the younger brother of Ferenc Némethi, was captured by Imre Thelekessy during the confrontations of 1558. As was the custom in such situations an exchange of hostages was proposed, but Thelekessy received instructions from Habsburg authorities to refuse such a compromise (ÖStA HHStA, UA, AA, Fasz. 79, Konv., A, f. 67-68; ÖStA HHStA, UA, AA, Fasz. 79, Konv., A, f. 71). Emperor Ferdinand himself requested that the prisoner should be moved from Kassa to Vienna (ÖStA HHStA, UA, AA, Fasz. 79, Konv., B, f. 11).

In addition, Ferdinand I confiscated several proprieties of the Némethi family in Zemplén, Ung and Abaúj counties (MNL OL, A 57, Libri regii, vol. 3, f. 422, 484, 511, 553, 554). All these actions had a single purpose, to convince Ferenc Némethi that it was in his best interest to join the Habsburgs. Nevertheless, the captain of Tokaj was resilient and maintained his first political option, loyalty to Queen Isabella and her son John Sigismund. In 1564, Lazarus Schwendi besieged Tokaj. While he was personally leading the defenders, Ferenc Némethi was gravely wounded and died a few days later. The Habsburgs were finally able to retake the fortress of Tokaj and, in its cellars, they found 4,000 barrels of the finest wine produced in the region (Németh, 2005, pp. 88-90).

\section{THE PEACE TREATY OF SPEYER (1570-1571)}

After decades of intermittent confrontations and negotiations, John Sigismund Szapolyai and Maximilian II of Habsburg reached an agreement. The treaty was signed by the Transylvanian ruler at Alba Iulia on the $1^{\text {st }}$ of December 1570 . On the $10^{\text {th }}$ of March 1571 , the treaty was ratified at Speyer in the presence of Emperor Maximilian II of Habsburg and a delegation of Transylvanian nobles led by Gaspar Bekes. John Sigismund Szapolyai had very little time to enjoy the benefits of peace because he died four days later (14 March 1571) (Lukinich, 1918, p. 
131; Fodor \& Oborni, 2020, p. 153). According to the treaty, John Sigismund gave up on the title of elected King of Hungary and became Prince of Transylvania and the Partium region (Princeps Transylvaniae et partium regni Hungariae eidem annexarum). The long dispute between the Szapolyai and Habsburg families for the heritage of the Hungarian Crown was finally over. The dispute would have probably ended anyway because John Sigismund died without leaving a legitimate heir to the throne and the Szapolyai dynasty was extinct.

The most important consequence of the Speyer Peace Treaty was the establishment of a more or less stable delimitation between Transylvania and Habsburg Hungary. At the same time, it was an official acknowledgement of the new state which would be called the Principality of Transylvania. The territorial settlement was an official recognition of the previous military confrontations, and the western edges of Transylvania were closer to what we might define as a modern linear border. A sinuous line of delimitation, sometimes rather unclear, traversed a vast region situated between the Tisza River and the Western Carpathians. In the south, Transylvania maintained control over the Banat of Caransebes and Lugoj and over a significant part of Zarand County. Further north, Bihor County and the fortress of Oradea were the most important economic and strategic possessions of the rulers from Alba lulia. In the north-west, Crasna, Middle Szolnok and Maramureș Counties were acknowledged as Transylvanian territories. The Habsburgs were the undisputed Kings of Hungary and maintained control over the territories and fortifications they had conquered in the previous decades like Tokaj, Munkács and Satu Mare (Lukinich, 1918, pp. 132-133; Borcea, 1978, p. 113; Tătar, 2003).

\section{CONCLUSIONS}

During the second half of the sixteenth century, the western edge of Transylvania can be characterised as a frontier rather than a modern linear border. However, the process of linearisation is evident in the effort of establishing a new political boundary, beyond traditional lines and natural obstacles such as rivers and mountain ranges. The terms frontier and borderland are more appropriate because contemporary sources refer to a vast and rather vague region where political authorities (Transylvanian, Habsburg and Ottoman) often overlapped. This peculiar situation is best illustrated by the case of Debrecen in 1567. The largest urban settlement under the official authority of John Sigismund Szapolyai, Debrecen paid taxes to the neighbouring empires as well: 3,200 florins to Transylvania, 2,000 florins to the Ottoman Empire, and 1,000 florins to Royal Hungary (Makkai, 2001, pp. 680-681).

Fortifications (fortresses, castles, or larger fortified settlements) were the most important landmarks of early modern borderlands. They represented strategic points of military and political control. The faction which controlled the major fortifications of an area had access to local resources and tax collection. Both Habsburg and Transylvanian rulers acknowledged the importance of a well-organised network of strongholds and invested important resources in their modernisation. Many fortifications from the western Transylvanian frontier were modernised through the building of bastions during the middle and the second half of the sixteenth century: Timișoara, Lipova, Deva, Ineu, Oradea, Șimleu, Chioar, Hust, Satu-Mare, and Tokaj. Fortifications were complex frontier-based institutions with a material (walls, weapons, ammunition, objects of daily use) and human (garrison, auxiliary staff) component. The large estates which surrounded most borderland fortresses were an important source of income and kept under direct control a significant number of settlements (villages and market towns): Deva - 40 settlements (38 villages and 2 market towns); Șiria - 13 settlements, Ineu - 10 
settlements, Oradea - 4,761 fiscal units (households), Șimleu - 49 settlements (47 villages and 2 market towns), Chioar - 67 settlements (one market town and 66 villages), Hust - 16 settlements (205.5 households) and Satu Mare - 186 settlements.

Local elites had an important role in the organisation of early modern frontiers. This social aspect of frontier management has been thoroughly researched in the case of the Ottoman Empire. Beginning with Paul Wittek, author of the ghaza (Holy War) thesis, many historians have focused their research on the frontier culture and ideology of medieval and early modern sultans. Most of them agree upon the important role played by the so called "marcher lords" in defending and expending the confines of the Sublime Porte. The European borderland of the empire was entrusted to marcher lords' (uç beğler) descendants of prominent state-founding dynasties such as the Evrenosoglu, Mihaloglu, Turahanoglu, Ishakoglu, and Malkoçoglu, who enjoyed a high degree of autonomy. Their authority was hereditary, and they had large retinues of soldiers (akıncIs) under their direct command (Heywood, 1999; Kiprovska, 2008; Kiprovska, 2015; Antov, 2017, pp. 41-94).

In a similar manner, but obviously on a different scale, the Szapolyai family entrusted the management of the western frontier of their state to frontier lords who exercised authority and influence over large areas: Peter Petrović (Timiș area and the Banat of Caransebeș and Lugoj), Stephen Báthory of Somlyó (Bihor, Crasna and Satu Mare counties), Kristóf Hagymássi (Inner Szolnok and Maramureș counties), Menyhárt Balassa (North-West Hungary) and Ferenc Némethi (Tokaj and Zemplén County). The lords from the western frontier had three features in common: they held important military and political offices on the frontier (usually captains of important fortifications), their family estates were situated in the borderlands, and they all had an important role in the political and military events that shaped the Transylvanian frontier. With the notable exception of Balassa, who betrayed John Sigismund and joined the Habsburgs, all the other above-mentioned lords remained loyal to the Szapolyai family. Through their political option, the Transylvanian "marcher lords" created a favourable context for the birth and consolidation of a new political and territorial identity.

\section{ACKNOWLEDGEMENT}

This research paper was supported by a grant of the Romanian Ministry of Education and Research, CNCS - UEFISCDI, project number PN-III-P1-1.1-TE-2019-0457, within PNCDIIII.

\section{REFERENCES}

Archives

Magyar Nemzeti Levéltár Országos Levéltára [National Archives of Hungary] (MNL OL), Budapest. A 57 - Magyar Kancelláriai Levéltár, Libri Regii, vol. 3.

Österreichisches Staatsarchiv, Haus-, Hof- und Staatsarchiv, Vienna, Ungarische Akten, Allgemeine Akten (ÖStA HHStA, UA, AA). Fasz. 79. Konv. A.

Monographs and articles

ABULAFIA, D. (2016). Introduction: Seven Types of Ambiguity, c. 1100-c. 1500. In Abulafia, D. \& Berend, N. (eds.), Medieval Frontiers: Concepts and Practices (pp. 1-34). London and New York: Routledge.

ANGHEL, GH. (1972). Cetăți medievale din Transilvania [Medieval Fortifications in Transylvania]. Bucureşti: Editura Meridiane. 
ANTOV, N. (2017). The Ottoman "Wild West": The Balkan Frontier in the Fifteenth and Sixteenth Centuries. Cambridge, New York: Cambridge University Press.

ARDELEAN, F.N. (2008-2009). Legislaţie militară şi politică fiscală în timpul lui loan Sigismund Zápolya (1556-1570) [Military Legislation and Fiscal Policy during the Reign of John Sigismund Zápolya (1556-1570)]. Acta Musei Napocensis, 45-46(II), 39-53.

ARDELEAN, F.N. (2017). Military Leadership in the Transylvanian Principality. The Captain General in the Second Half of the 16th Century. Banatica, 26(2), 337-349.

ARDELEAN, F.N. (2017). On the Foreign Mercenaries and Early Modern Military Innovations in East Central Europe. The Army of Castaldo in Transylvania and the Banat 1551-1553. In Bujdosné Pap, G., Fejér, I., \& Szilasi, Á.H. (eds.), Mozgó Frontvonalak. Háború és diplomácia a várháborúk időszakában 1552-1568 [Moving Frontiers. War and Diplomacy during the Time of the Fortress War 1552-1568], Studia Agriensia, 35 (pp. 117-128). Eger: Dobó István Vármúzeum.

ARDELEAN, F.N. (2019). Organizarea militară în principatul Transilvaniei (1541-1691): Comitate și domenii fiscale [Military Organisation in the Principality of Transylvania (1541-1691): Counties and Fiscal Estates]. ClujNapoca: Academia Română. Centrul de Studii Transilvane.

ARDELEAN, F.N. \& ISAILOVIĆ, N. (2021). From Croatia to Transylvania: War, Migration, and Adaptive Strategies in the Case of the Perušić Family (15th-17th Centuries). Povijesni prilozi, 60, 211-254.

ARDELEAN, F.N. (2021). War and Social Conflicts in Early Modern Border Areas: Colonel Ludovicus de La Borde and Satu Mare (Szatmár) Fortress (1673-77). Hiperboreea, 8(1), 16-37.

BARAMOVA, M. (2010). Border Theories in Early Modern Europe. European History Online (EGO), published by the Institute of European History (IEG), Mainz 2010-12-03. Retrieved 18 March 2020, from http://iegego.eu/en/threads/crossroads/border-regions/maria-baramova-border-theories-in-early-modern-europe

BORCEA, L. (1978). Oamenii din cetăţile de margine ale Nord-Vestului Transilvaniei în epoca principatului (secolele XVI-XVII) [People from Frontier Frotifications of North-West Transylvania during the Age of the Principality (16 ${ }^{\text {th }}-17^{\text {th }}$ Centuries) ]. Crisia, VIII, 113-129.

CENTORIO DEGLI HORTENSII, A. (1565). Comentarii della guerra di Transilvania. Vinegia: Appresso Gabriel Giolito de' Ferrari.

CÎMPEANU, L. (2018). „Domnul fie lăudat [...] turcii au predat cetatea”: Cucerirea Lipovei Otomane de către transilvăneni în august 1595 ["God be praised [...] the Turks Surrendered the Fortress": The Conquest of Ottoman Lipova by the Transylvanians, on the 25th of August 1595]. Historia Urbana, XXVI, 97-111.

CZIMER, K. (1893). Temesvár megvétele 1551-1552 [The Conquest of Temesvár 1551-1552]. Hadtörténelmi Közlemények, VI, 15-71, 196-229, 303-376.

DESCHMANN, A. (1991). Huszt vára - A Máramarosi sóbányák őre [Huszt Fortress - the Guardian of the Salt Mines in Maramureș]. Múemlékvédelem [Conservation of Historical Monuments], 35(3), 156-164.

DIACONESCU, M. (2012). Izvoare de antroponimie şi demografie istorică. Conscripţiile cetăţii Sătmar din 1569-1570 [Anthroponimic and Demographic Historical Sources. The Conscription of Sătmar Fortress from 1569-1570]. Cluj-Napoca: Editura Mega.

DÖRNER, E.A. (2018). Circumstanțele formării Principatului Transilvaniei și a curții princiare. Primul deceniu de evoluție (1541-1551) [The Circumstances for the Founding of the Transylvanian Principality and the Princely Court. The First Decade of Evolution (1541-1551)]. Banatica, 28, 497-522.

ESSER, R. \& ELLIS, S.G. (2013). Introduction: Border Regions in early Modern Europe. In Esser, R. \& Ellis, S.G. (eds.), Frontier and Border Regions in Early Modern Europe (pp. 7-17). Hanover: Wehrhahn Verlag.

FENEŞAN, C. (1997). Constituirea principatului autonom al Transilvaniei [The Formation of the Autonomous Principality of Transylvania]. Bucureşti: Editura Enciclopedică.

FENEŞAN, C. (2001). Doi cronicari ardeleni din secolul al XVII-lea [Two Transylvanian Chroniclers of the Seventeenth Century]. Timişoara: Editura de Vest.

FENEŞAN, C. (2016). Ioan Kendefi, Ioan Glesán şi Nikola Crepović - Fideles pragmatici în lupta pentru stăpânirea Transilvaniei şi Banatului (mijlocul secolului al XVI-lea) [Ioan Kendefi, Ioan Glesán and Nikola Crepović Fideles pragmatici in the Fight for the Control of Transylvania and Banat (Middle of the $16^{\text {th }}$ Century)]. Banatica, 26(II), 309-335. 
FENEŞAN, C. (1999-2000). Le statut de dépendance de la principauté de Transylvanié envers la Porte en 1541. Revue des études sud-est européennes, XXXVII - XXXVIII, 79-91.

FODOR, P. \& OBORNI, T. (2020). Between Two Great Powers: The Hungarian Kingdom of the Szapolyai Family. In Fodor, P. \& Varga, Sz. (eds.), A Forgotten Hungarian Royal Dynasty: The Szapolyais (pp. 127-163). Budapest: Research Centre for the Humanities.

GOETTLICH, K. (2019). The Rise of Linear Borders in World Politics. European Journal of International Relations, 25(1), 203-228.

GROMO, G. (1945). Compendio di tutto il regno posseduto dal re Giovanni Transilvano et di tutte le cose notabili d'esso regno (Sec. XVI). Edited by Decei, A. Alba Iulia: Tip. „Alba”.

GROZA, L. (1993). Cetatea Caransebeș - câteva precizări cronologice [The Fortress of Caransebeș - a Few Chronological Issues]. Banatica, 12(2), 89-99.

HEGYI, K. (2019). Ottoman Defence System in Hungary. In Fodor, P. (ed.), The Battle for Central Europe: The Siege of Szigetvár and the Death of Süleyman the Magnificent and Nicholas Zrínyi (1566) (pp. 309-321). Leiden, Boston: Brill.

HEGYI, Ö. (1900). Székely Antal tudósítása a Hadadi csatáról (1562) [The Report of Székely Antal on the Battle of Hadad (1562)]. Történelmi Tár [Historical Magazine], I, 142-144.

HEYWOOD, C. (1999). The Frontier in Ottoman History: Old Ideas and New Myths. In Power, D. \& Standen, N. (eds.), Frontiers in Question: Eurasian Borderlands, $700-1700$ (pp. 228-250). New York: Palgrave Macmillan.

HOLBAN, M., ALEXANDRESCU-DRESCA BULGARU, M.M., \& CERNOVODEANU, P. (eds.) (1970). Călători străini despre Jările Române, vol. II. [Foreign Travellers through the Romanian Lands, vol. II]. Bucureşti: Editura Științifică și Enciclopedică.

HORN I. (2012). A hatalom pillérei. A politikai elit az Erdélyi Fejedelemség megszilárdulásának időszakában (15561588) [Pillars of Power. The Political Elite during the Period of Consolidation of the Transylvanian Principality (1556-1588)]. Ph.D. Dissertation. Hungarian Academy of Sciences, Budapest, Retrieved 18 March 2020, from http://real-d.mtak.hu/581/

HOSSU, V. (2003). Nobilimea Chioarului [The Nobility of Chioar]. Baia Mare: Biblioteca Judeţeană „Petre Dulfu”.

JAKÓ, ZS. (1940). Bihar megye a török pusztítás elött [Bihar County before the Turkish Destruction]. Budapest: Sylvester Nyom da RT.

JAKÓ, ZS. (1989-1993). Despre numirea voievozilor Transilvaniei [On the Appointment of Transylvanian Voivodes]. Acta Musei Napocensis, 26-30, 33-44.

KIPROVSKA, M. (2008). The Mihaloğlu Family: Gazi Warriors and Patrons of Dervish Hospices. The Journal of Ottoman Studies, XXXII, 193-222.

KIPROVSKA, M. (2015). Shaping the Ottoman Borderland: The Architectural Patronage of the Frontier Lords from the Mihaloğlu Family. In Baramova, M., Boykov, G., \& Parvev, I. (eds.), Bordering Early Modern Europe (pp. 185-220). Wiesbaden: Harrassowitz Verlag.

KORPÁS, Z. (2000). La correspondencia de un soldado español de las guerras en Hungría a mediados del siglo XVI. Comentarios al diario de Bernardo de Aldana (1548-1552). Hispania, LX(3), 206, 881-909.

KORPÁS, Z. \& SZABÓ, J.B. (2020). "If They Came as a Legation, They Are Many, If They Are Soldiers, They Are Few" The Military Background of the 1551 Attempt to Unite Hungary. In Máté, Á. \& Oborni, T. (eds.), Isabella Jagiellon Queen of Hungary (1539-1559) (pp. 147-162). Budapest: Akadémia Kiadó.

KOVÁCS, A. (2005). Voievozii Transilvaniei și evoluția instituției voievodale până la începutul secolului al XV-lea [The Voivodes of Transylvania and the Evolution of the Voivodal Institution until the Beginnings of the $15^{\text {th }}$ Century]. Ph.D. Dissertation. Romanian Academy, „Nicolae lorga” Institut of History, București.

KOVÁCS, A. (2013). Szilágysomlyó vára a 16. Században [Szilágysomlyó Fortress in the $16^{\text {th }}$ Century]. Dolgozatok az Erdélyi Múzeum érem- és régiségtárából, VIII, 95-106.

KOVÁCS P.K. (2009). Planimetria cetății bastionare de la Satu Mare în context European [The Plan of Satu Mare Fortress and Its European Context]. Ars Transsilvaniae, XIX, 27-35.

KOVÁCS, K. (2012). Fortresses-Building in 16th Century Transylvania. The Recruitment of Labour Force. Transylvanian Review, XXI(Supplement 2), 163-181. 
LANGER, CH. \& FERNÁNDEZ-GÖTZ, M. (2020). Boundaries, Borders and Frontiers: Contemporary and Past Perspectives. In Warburton, D.A. (ed.), Political and Economic Interaction on the Edge of Early Empires, eTopoi: Journal for Ancient Studies, Special Volume 7, 33-47.

LUKINICH, I. (1918). Erdély területi változásai a török hódítás korában 1541-1711 [Territorial Changes in Transylvania during the Age of the Turkish Conquest 1541-1711]. Budapest: Magyar Tudományos Akadémia.

MAGINA, A. (2011). Conscripția și inventarul bunurilor cetății Ineu în anul 1605 [The Conscription and Inventory of Ineu Fortress in 1605]. Banatica, 21, 90-104.

MAGINA, A. (2013a). At the border of Transylvania: The County of Severin/ the district of Caransebeș in the $16^{\text {th }}-17^{\text {th }}$ Centuries. Transylvanian Review, XXII(Supplement 4), 295-306.

MAGINA, A. (2013b). Fortificațiile Lipovei și Timișoarei în preajma cuceririi otomane (1551) [The Fortifications of Lipova and Timișoara on the Eve of the Ottoman Conquest (1551)]. Analele Banatului, S.N., ArheologieIstorie, XXI, 275-279.

MAgINA, A. (2015). Peter Petrović and Protestantism: Aspects Concerning the Patronage of the Reformation during Its Early Period. Initial. A Review of Medieval Studies, 3, 139-159.

MAKKAI, L. (2001). The First Period of the Principality of Transylvania (1526-1606). In Köpeczi, B. (ed.), History of Transylvania, vol. I. New York: Columbia University Press.

MAKSAY, F. (1990). Magyarország birtokviszonyai a 16. század középen, vol. I [Land Tenure in Hungary during the Middle of the $16^{\text {th }}$ Century, vol. I]. Budapest: Akadémiai Kiadó.

MARTA, D. (2013). Cetatea Oradiei. De la începuturi până sfârşitul secolului al XVII-lea [The Fortress of Oradea. From the Beginning to the End of the $17^{\text {th }}$ Century]. Oradea: Editura Muzeului Țării Crișurilor.

MASI, G. (2015). I rapporti tra il Granducato di Toscana e il Principato di Transilvania (1540-1699). Roma: Aracne editrice.

MILES, M. (1670). Siebenbürgischer Würg-Engel oder chronicalischer Anh. d. 15 sec. nach Christi Geburth aller theils in Siebenbürgen theils Ungern und sonst Siebenbürgen angräntzenden Ländern fürgelauffener Geschichten Worausz nicht nur allein $d$. grewligst bluttige Anschläge, Kriege und Zeittungen $d$. Ober-Regenten Sachsischer Nation. Hermannstadt: Fleischer.

MOLNÁR, D. (2020). A XVI. századi északkelet-magyarországi fönemesség hivatalviselési, hivatal- és birtokszerzési gyakorlata - Losonczy Antal és István pályája [The strategies of the north-eastern Hungarian nobility in the 16th century - the lives of Anthony and Stephan Losonczy]. Ph.D. Dissertation. Eötvös Loránd University, Faculty of Humanities, Budapest. Retrieved 18 March 2020, from https://edit.elte.hu/xmlui/handle/10831/58106

NÉMETH, C. (2005). Némethi Ferenc, Tokaj kapitánya. Sárospataki Füzetek, 9(2) 74-90.

OBORNI, T. (2004). From Province to Principality: Continuity and Change in Transylvania in the First Half of the Sixteenth Century. In Zombori, I. (ed.), Fight against the Turk in Central-Europe in the First Half of the Sixteenth Century (pp. 165-179). Budapest: Magyar Egyháztörténeti Enciklopédia Munkaközösség.

PÁLFFY, G. (2000). The Origins and Development of the Border Defence System against the Ottoman Empire in Hungary (up to the Early Eighteenth Century). In Dávid, G. \& Fodor, P. (eds.), Ottomans, Hungarians and Habsburgs in Central Europe: The Military Confines in the Era of Ottoman Conquest (pp. 3-71). Leiden: Brill.

PÁLOSFALVI, T. (2018). From Nicopolis to Mohács: A History of Ottoman-Hungarian Warfare, 1389-1526. Leiden Boston: Brill.

POWER, D. (1999). Frontiers: Terms, Concepts, and the Historians of Medieval and Early Modern Europe. In Power, D. \& Standen, N. (eds.), Frontiers in Question: Eurasian Borderlands, $700-1700$ (pp. 1-12). New York: Palgrave Macmillan.

PRODAN, D. (1967). Iobăgia în Transilvania în secolul al XVI-lea, vol. I. [Serfdom in Transylvania in the 16 Century]. București: Editura Academiei.

STANDEN, N. (1999). Nine Case Studies of Premodern Frontiers. In Power, D. \& Standen, N. (eds.), Frontiers in Question: Eurasian Borderlands, 700-1700 (pp. 13-32). New York: Palgrave Macmillan. 
SZAKÁLY, F. (ed.) (1986). Bernardo de Aldana magyarországi hadjárata 1548 - 1552 [The Hungarian Campaign of Bernardo de Aldana 1548-1552]. Translated by László Scholz. Budapest: Európa könyvkiadó.

SZILÁGYI, S. (volume edited and prefaced by) (1876a.). Erdélyi Országgyülési Emlékek, vol. I [Memories of the Transylvanian Diet, vol. I]. Budapest: Magyar Tudományos Akadémia.

SZILÁGYI, S. (volume edited and prefaced by) (1876b.). Erdélyi Országgyúlési Emlékek, vol. II [Memories of the Transylvanian Diet, vol. II]. Budapest: Magyar Tudományos Akadémia.

TĂTAR, O. (2003). Tratatul de la Speyer (1570) dintre Maximilian al II-lea şi Ioan Sigismund Zápolya şi statutul politico-teritorial al Transilvaniei pe plan European [The Speyer Peace Treaty (1570) between Maximilian II and John Sigismund Zápolya and the Political and Territorial Status of Transylvania in the European Context]. Annales Universitatis Apulensis, Historica, 7, 191-197.

ȚIGĂU, D.-L. (1998). Banii de Caransebeș și Lugoj. Considerații asupra atribuțiilor și competențelor acestora [The Bans of Caransebeș and Lugoj. Considerations about Their Attributes and Prerogatives]. Studii și Materiale de Istorie Medie, XVI, 225-241.

VARGA, Sz. (2020). Péter Petrovics (1487-1557) in the Service of Queen Isabella. In Máté, Á. \& Oborni, T. (eds.), Isabella Jagiellon Queen of Hungary (1539-1559) (pp. 327-347). Budapest: Akadémia Kiadó.

VERESS, A. (1929). Documente privitoare la istoria Ardealului, Moldovei şi Jării Româneşti. Acte şi scrisori, vol. I [Documents Concerning the History of Transylvania, Moldavia and Wallachia. Documents and Letters, vol. I]. București: Cartea Românească.

VERESS, A. (1933a). Documente privitoare la istoria Ardealului, Moldovei şi Jării Româneşti, Acte şi scrisori, vol. VI [Documents Concerning the History of Transylvania, Moldavia and Wallachia. Documents and Letters, vol. VI]. București: Cartea Românească.

VERESS, A. (1933b). A történetíró Báthory István király [King Báthory István the Historian]. Cluj-Kolozsvár: Minerva.

VIROVECZ, N. (2017). Kereszténység szolgálata vagy politikai árulás? Balassa Menyhárt 1562. évi pártváltása és az északkeleti várháborúk [In the Service of Christianity or a Political Betrayal? Menyhárt Balassa's Switch of Allegiance in 1562 and the Northeastern Castle Sieges]. In Bujdosné Pap, G., Fejér, I., \& Szilasi Á.H. (eds.), Mozgó Frontvonalak. Háború és diplomácia a várháborúk időszakában 1552-1568 [Moving Frontiers. War and Diplomacy during the Time of the Fortress War 1552-1568], Studia Agriensia, 35 (pp. 255-283). Eger: Dobó István Vármúzeum.

VIROVECZ, N. (2021). Shifting Allegiances and the Questions of Resilience: Lords of the Hungarian and Transylvanian Border during the Fortress Wars of 1560's. In Kopeczny, Zs. (ed.), Politics and Society in Central and SouthEast Europe: Life under the Shadow of the Ottoman Empire's Expansion (15th-16th Centuries) (pp. 101-117). Cluj-Napoca: Mega.

WOLF, R. (1981). Cetatea Şimleului. Schiţă monografică [The Fortress of Șimleu. A Monographic Sketch]. Acta Musei Porolissensis, V, 395-409. 